\title{
Optical and structural analysis of solar selective absorbing coatings based on $\mathrm{AlSiO}_{\mathrm{x}}: \mathrm{W}$ cermets
}

\author{
D. Dias ${ }^{\text {a }}$, L. Rebouta ${ }^{\mathrm{a}, *}$, P. Costa ${ }^{\mathrm{a}}$, A. Al-Rjoub ${ }^{\mathrm{a}}$, M. Benelmeki ${ }^{\mathrm{b}}$, C.J. Tavares ${ }^{\text {a }}$, N.P. Barradas ${ }^{\text {c }}$, E. Alves ${ }^{\mathrm{d}}$, \\ P. Santilli ${ }^{\mathrm{e}, 1}$, K. Pischow ${ }^{\mathrm{e}}$ \\ ${ }^{a}$ Centre of Physics, University of Minho, Campus de Azurém, 4800-058 Guimarães, Portugal \\ ${ }^{\mathrm{b}}$ Norwegian University of Science and Technology, Department of Materials Science Engineering, NO-7491 Trondheim, Norway \\ ' Centro de Ciências e Tecnologias Nucleares, Instituto Superior Técnico, EN 10, km 139.7, 2695-066 Bobadela LRS, Portugal \\ d Campus Tecnológico e Nuclear, Instituto Superior Técnico, EN 10, km 139.7, 2695-066 Bobadela LRS, Portugal \\ e Savo Solar Oy, Insinöörinkatu 7, 50100 Mikkeli, Finland
}

\section{A R T I C L E I N F O}

Article history:

Received 24 January 2017

Received in revised form 20 April 2017

Accepted 21 April 2017

\section{Keywords:}

Solar selective absorber

$\mathrm{AlSiO}_{\mathrm{x}}$ :W cermet

Optical constants

Dielectric function modelling

Sputtering, solar thermal

\begin{abstract}
A B S T R A C T
It is reported in this work the development and study of the optical and structural properties of a solar selective absorber cermet based on $\mathrm{AlSiO}_{\mathrm{x}}: \mathrm{W}$. A four-layer composite film structure, $\mathrm{W} / \mathrm{AlSiO}_{\mathrm{x}}: \mathrm{W}(\mathrm{HA}) /$ $\mathrm{AlSiO}_{\mathrm{x}}: \mathrm{W}(\mathrm{LA}) / \mathrm{AlSiO}_{\mathrm{x}}$, was deposited on stainless steel substrates using the magnetron sputtering deposition method. Numerical calculations were performed to simulate the spectral properties of multilayer stacks with varying metal volume fraction cermets and film thickness. The chemical analysis was performed using X-ray photoelectron spectroscopy and the results show that in the high metal volume fraction cermet layer, $\mathrm{AlSiO}_{\mathrm{x}}: \mathrm{W}(\mathrm{HA})$, about one third of $\mathrm{W}$ atoms are in the $\mathrm{W}^{0}$ oxidation state, another third in the $\mathrm{W}^{\mathrm{x}+}$ oxidation state and the last third in the $\mathrm{W}^{4+}, \mathrm{W}^{5+}$ and $\mathrm{W}^{6+}$ oxidation states. The X-ray diffractograms of $\mathrm{AlSiO}_{\mathrm{x}}: \mathrm{W}$ layers show a broad peak indicating that both, $\mathrm{W}$ and $\mathrm{AlSiO}_{\mathrm{x}}$, are amorphous. These results indicate that this film structure has a good spectral selective property that is suitable for solar thermal applications, with the coatings exhibiting a solar absorptance of $94-95.5 \%$ and emissivities of $8-9 \%\left(\right.$ at $100{ }^{\circ} \mathrm{C}$ ) and $10-14 \%$ (at $400{ }^{\circ} \mathrm{C}$ ). The samples were subjected to a thermal annealing at $450{ }^{\circ} \mathrm{C}$, in air, and $580^{\circ} \mathrm{C}$, in vacuum and showed very good oxidation resistance and thermal stability. Morphological characterizations were carried out using scanning electron microscopy and atomic force microscopy. Rutherford Backscattering experiments were also performed to analyze the tungsten depth profile.
\end{abstract}

(c) 2017 Elsevier Ltd. All rights reserved.

\section{Introduction}

Nowadays, the interest in renewable energies has a high growth, particularly in the Concentrated Solar Power (CSP) technologies. These are one of several renewable energy technologies with significant potential that are benefiting from a great technological improvement and are gradually more used in different areas around the world (International Energy Agency, 2014; Sunshot Vision Study, 2012; Fernández-García et al., 2010; Viebahn et al., 2011). Linear and point focus systems are the main receivers used in CSP plants. The parabolic trough linear receivers rely on a solar selective absorber coating that still has room for

\footnotetext{
* Corresponding author.

E-mail address: rebouta@fisica.uminho.pt (L. Rebouta).

1 Present address: Kenosistec s.r.l., Via delle Scienze, 23, 20082 Binasco, MI, Italy.
}

improvement, which can be achieved by emissivity reduction, as well as increase its durability and oxidation resistance, ideally under air (Sunshot Vision Study, 2012). In case of parabolic trough linear receivers working with synthetic oil as heat transfer fluid (HTF), which operate below $400^{\circ} \mathrm{C}$, the commercialized solar selective coatings already display high solar absorptance $\left[\alpha_{\mathrm{s}}>95 \%\right)$ and low thermal emittance $\left(\varepsilon \quad\left(400{ }^{\circ} \mathrm{C}\right)<10 \%\right)$ (Burkholder and Kutscher, 2009). In case of using molten salt as HTF, these systems should withstand operating temperatures in the range of $350-550^{\circ} \mathrm{C}$ (Archimede Solar Energy).

The spectrally selective coating should have low reflectance in visible and near infrared (IR) regions $(\lambda<2 \mu \mathrm{m})$ to absorb the incident solar radiation. In order to prevent thermal losses the coating should also have a high IR reflectance $(\lambda>2 \mu \mathrm{m})$ (Seraphin, 1976; Selvakumar and Barshilia, 2012). This implies a drastic reflectance modification at a cut-off wavelength around $2 \mu \mathrm{m}$ (Seraphin, 1976; 
Kennedy, 2002). The position of this cut-off wavelength is related with the black body emission at high temperatures, which starts to overlap the solar radiation spectra in the infrared tail. Thus, that position is determined by the compromise between solar irradiance (to be absorbed) and radiative emission of the receiver (to be avoided). The spectral selectivity can be obtained by the association of several materials in a multilayer with adequate optical properties. The first layer is a back IR reflector metallic layer with high electrical conductivity ( $\mathrm{Cu}$ and $\mathrm{Al}$ for low temperature absorbers and Mo, $\mathrm{W}$ and Ni for medium and high temperature absorbers (Bogaerts and Lampert, 1983; Kennedy, 2002). The remaining stack is comprised by a layer structure for solar radiation absorption and finally an antireflection layer. For high temperature applications, the oxides are the most common antireflection layers $\left(\mathrm{Al}_{2} \mathrm{O}_{3}\right.$ or $\mathrm{SiO}_{2}$ as single layer, or a combination of $\mathrm{SiO}_{2}$ and $\mathrm{TiO}_{2}$ layers (Kennedy, 2010) due to its optical properties, as well as to its thermal stabilities.

A very high solar absorption can be achieved when the coating has a graded refractive index and extinction coefficient, which should be highest at the interface metal/substrate (infrared reflector) and then gradually decreasing towards the surface. This grading behaviour can be simplified by the use of few layers (2-4 layers) (Zhang and Mills, 1992; Yin and Collins, 1995) with continuously decreasing refractive index, namely using a low absorption/ high absorption, (LA/HA) double layer. The use of two absorbing layers allows the absorption of solar radiation through the materials intrinsic absorption and by phase interference. This can be achieved using a double cermet (Antonaia et al., 2010; Farooq and Hutchins, 2002; Wäckelgård et al., 2015; Zhang et al., 1996; Rebouta et al., 2015), where the metal volume fraction is used to adjust the refractive index and extinction coefficient of each layer, or by a layer structure based on two different materials with adequate optical constants, which can be, for example, those based on transition metal nitride/oxynitride or carbide/nitride layers (Barshilia et al., 2008; Du et al., 2011; Rebouta et al., 2015; Barshilia et al., 2008; An et al., 2015; Rebouta et al., 2012; Feng et al., 2015; Usmani and Dixit, 2016).

The ceramic-metal composite coating (cermet) is the most common solution used for high temperature applications, where the low metal volume fraction cermet layer works as low absorption layer and the high metal volume fraction cermet layer as the high absorption layer. The concept offers a broad range of options for solar selectivity optimization and it depends on the proper choice of its constituents. Several combinations of the ceramic-metal composite have been tested and reported, using mainly $\mathrm{Al}_{2} \mathrm{O}_{3}$, $\mathrm{SiO}_{2}, \mathrm{Si}_{3} \mathrm{~N}_{4}, \mathrm{TiO}_{2}$ and AlN as matrix. These ceramic materials have been chosen due to its inherent high chemical and thermal stability, together with metals inclusions, such as $\mathrm{W}, \mathrm{Mo}, \mathrm{Ag}, \mathrm{Ni}, \mathrm{Pt}, \mathrm{Nb}$, and $\mathrm{V}$, bearing some of these metals a relatively good oxidation resistance. Those combinations are, for example, $\mathrm{Mo}-\mathrm{Al}_{2} \mathrm{O}_{3}$ (Zhang et al., 1996; Teixeira et al., 2001; Cheng et al., 2013), $\mathrm{W}-\mathrm{Al}_{2} \mathrm{O}_{3}$ (Antonaia et al., 2010; Rebouta et al., 2015; Cao et al., 2015), Ni- $\mathrm{Al}_{2} \mathrm{O}_{3}$ (Boström et al., 2011; Craighead and Buhrman,

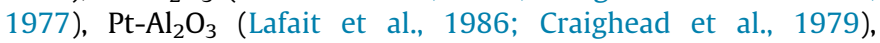
$\mathrm{V}-\mathrm{Al}_{2} \mathrm{O}_{3}$ (Farooq and Hutchins, 2002), $\mathrm{Mo}-\mathrm{SiO}_{2}$ (Esposito et al., 2009; Zheng et al., 2013; Wang et al., 2011), W-SiO 2 (Wäckelgård et al., 2015), Ag-SiO 2 (Granqvist and Hunderi, 1978), $\mathrm{Ni}-\mathrm{SiO}_{2}$ (Farooq et al., 1998), Nb-TiO 2 (Wäckelgård et al., 2015), W-AlN (Zhang and Shen, 2004) and Mo- $\mathrm{Si}_{3} \mathrm{~N}_{4}$ (Céspedes et al., 2014).

This paper presents the development of solar absorber coatings for high operation temperatures $\left(>400{ }^{\circ} \mathrm{C}\right)$, based on $\mathrm{AlSiO}_{\mathrm{x}}: \mathrm{W}$ cermets. Alumino-Silicate refractories have a high temperature volume stability and strength, and excellent resistance to thermal spalling. The use of an $\mathrm{AlSi}_{\mathrm{x}}$ target allows for obtaining an antireflection layer with similar refractive index of $\mathrm{SiO}_{2}$, while using the same $\mathrm{AlSi}_{\mathrm{x}}$ target for high and low absorption layers. The functionality of the multilayer structures was verified through the solar absorptance and emissivity measurements. The optical design of multilayered coatings was performed through tailoring of the spectral optical constants of the single layers, using the modelling software SCOUT (Theiss, 2002).

\section{Experimental details}

The $\mathrm{W}$ metallic back layer was deposited on glass and stainless steel (SS) substrates by DC magnetron sputtering in static mode from a pure tungsten target, using a current density of $12.5 \mathrm{~mA}$ / $\mathrm{cm}^{2}$. The optical characterization of this layer was previously reported (Rebouta et al., 2015). Subsequently, the $\mathrm{AlSiO}_{\mathrm{x}}$ :W cermets were deposited by simultaneous sputtering from pure metal $\mathrm{W}$ and $\mathrm{Al}$ targets, the latter with 9 small silicon disc pellets $(1 \mathrm{~cm}$ in diameter) within the erosion zone. The $10 \mathrm{~cm}$ in diameter circular targets were placed horizontally, while the substrate holder rotated with a constant speed over them. The $\mathrm{AlSiO}_{\mathrm{x}}: \mathrm{W}$ cermet films with varying $\mathrm{W}$ volume fraction were obtained by maintaining constant the sputter current for the AlSi ${ }_{x}$ target $\left(6.2 \mathrm{~mA} / \mathrm{cm}^{2}\right)$ and $\mathrm{O}_{2}$ flow $(5 \mathrm{sccm}$, corresponding to a partial pressure of $0.065 \mathrm{~Pa}$ ), and varying the current of the $\mathrm{W}$ target from $0.15 \mathrm{~A}$ to $0.75 \mathrm{~A}$. Two series were prepared using different substrate holder rotation speeds, 7 and $15 \mathrm{rpm}$.

The chemical analysis was performed using a X-ray photoelectron spectroscopy (XPS) equipment from Kratos - Axis Ultra DLD 39-306, equipped with a mono-Al $\mathrm{K} \alpha$ source operated at $300 \mathrm{~W}$. The spectra were modelled using the XPSPEAK41 software and the peaks were assumed to have a Gaussian shape and a Shirley type of background.

The crystalline structure of the absorber coating was studied using X-ray diffraction employing a Bruker AXS Discover D8, operating with $\mathrm{Cu}_{\mathrm{K} \alpha}$ radiation. X-ray diffraction measurements were performed using a $3^{\circ}$ incidence angle. Scanning Electron Microscopy (SEM) was performed with a NanoSEM - FEI Nova 200 (FEG/SEM) microscope. Film topography and roughness were examined using Atomic Force Microscope (Dimension Icon- Bruker) under scan adjust mode. RBS experiments were performed using a 3.0 MV Van der Graaff accelerator. A $2.0 \mathrm{MeV} \mathrm{He}^{+}$beam was used. The backscattered particles were detected by a surface barrier detector placed at $140^{\circ}$ to the beam direction.

Spectral transmittance and reflectance measurements were performed in the wavelength range of $0.25-2.5 \mu \mathrm{m}$, using a Shimadzu spectrophotometer. The reflectance measurements were performed with an incidence angle of $8^{\circ}$, using an integrating sphere attachment. The normal solar absorptance, $\alpha_{\text {sol }}$, is defined as a weighted fraction between absorbed radiation and incoming solar radiation and was determined using the spectral reflectance data and ASTM AM1.5D solar spectral irradiance. A Fourier Transform Infrared (FTIR) spectrophotometer from Agilent Technologies equipped with a gold integrating sphere and a $\operatorname{HgCdTe}$ (MCT) detector was used to measure the spectral reflectance in the infrared wavelength range, 1.6-16.7 $\mu \mathrm{m}$. The normal thermal emittance was calculated as the weighted fraction between emitted radiation and the Planck black body distribution at a specific temperature $\mathrm{T}$, using the spectral blackbody emissive power and the spectral reflectance (Trotter and Sievers, 1980). Reflectance measurements were performed using a gold thin film as a reference. Since gold has an absolute reflectance lower than $100 \%$, the reflectance of a copper plate was corrected multiplying the reflectance by a constant factor (lower than 1) in order to obtain a thermal emittance of $3 \%$ at $100{ }^{\circ} \mathrm{C}$. This correction was performed for all IR reflectance measurements. 


\section{Results}

\subsection{Deposition and optical properties}

The $\mathrm{W}$ layer was previously studied and its optical properties were already reported (Rebouta et al., 2015). In order to get high reflectivity it is necessary to have low oxygen content in the $\mathrm{W}$ layer, and different deposition rates were tested (target current densities of $6.2 \mathrm{~mA} / \mathrm{cm}^{2}$ and $12.5 \mathrm{~mA} / \mathrm{cm}^{2}$ ). The best result was obtained with the highest deposition rate, which is used in this work. The $\mathrm{W}$ layer improves significantly the reflectance of polished stainless steel to about $96 \%$ at $\lambda>2500 \mathrm{~nm}$, leading to an emissivity decrease from $\varepsilon=14 \%$ (SS substrate) to $\varepsilon=4 \%$ (at $80^{\circ} \mathrm{C}$ ), On the other hand, the $\mathrm{W}$ layer also contributes for solar radiation absorption, due to its absorptance coefficient of $42 \%$. The different cermet $\mathrm{AlSiO}_{\mathrm{x}}: \mathrm{W}$ layers deposited on glass substrates were prepared by varying the current applied to the $\mathrm{W}$ target. Optical spectroscopy in both transmittance and reflectance modes was used to characterize the optical properties of the films. The increase in $\mathrm{W}$ content in the films led to the expected gradual decrease of the transmittance and consequently to an increase in the reflectance, which is consistent with the increasing metallic character. Fig. 1 depicts the optical transmittance (Fig. 1a) and reflectance (Fig. 1b) data for representative $\mathrm{AlSiO}_{\mathrm{x}}: \mathrm{W}$ layers prepared with increasing $\mathrm{W}$ target current, as indicated in the legend of Fig. 1. By varying the $\mathrm{W}$ target current between 0 and $0.7 \mathrm{~A}$ it was possible to obtain a wide range of reflectance and transmittance values (and consequently optical constants), from which it is possible to select the layers with adequate optical constants and construct the desired optical stack. The $\mathrm{AlSiO}_{\mathrm{x}}$ layer has a high transmittance and low reflectance, which makes it suitable to be used as an antireflection layer. This enables the use of same AlSi target for cermet $\mathrm{AlSiO}_{\mathrm{x}}: \mathrm{W}$ layers and for the antireflection layer. The spectral reflectance and transmittance of these layers were modelled with SCOUT software, which allowed the calculation of the spectral optical constants (refractive index, n, and extinction coefficient, $\kappa$ ), besides the thickness of each individual layer. In this modelling procedure, an initial attempt was performed starting off with the dielectric functions obtained from individual $W$ and $\mathrm{AlSiO}_{\mathrm{x}}$ layers, based on the two phase composite models of Maxwell Garnett (Maxwell Garnett (1904) and (Bruggeman (1935)), however the results were not satisfactory. As it will be shown later in this manuscript, this can be due to the partial oxidation of $\mathrm{W}$ atoms. Thus, a one phase model was used instead, with a Drude term, representing unbound electron oscillators, a Lorentz term representing the bound harmonic oscillators (Kim et al., 1992), which was used to describe the intraband transitions into the upper half of the conduction band, and a OJL term (O_Leary et al., 1997) to describe the band gap transitions. A good agreement between the simulated and experimental data was obtained and the refractive index and extinction coefficient are plotted in Fig. 2 as a function of the wavelength, for the same samples shown in Fig. 1 (substrate holder rotation speed of $15 \mathrm{rpm}$ ).

As expected, the extinction coefficient of $\mathrm{AlSiO}_{\mathrm{x}}$ layer $(0 \mathrm{~mA})$ is almost zero and the refractive index is below 1.6 for wavelengths higher than $700 \mathrm{~nm}$. This fact is also consistent with a mixture of aluminium and silicon oxides, and makes this material a good antireflection layer. The refractive index and extinction coefficient increase with $\mathrm{W}$ content, as expected due to the increase of the metallic character. The thicknesses of these films were obtained from the fit to the experimental spectral transmittance and reflectance curves, and ranged from 70 to $91 \mathrm{~nm}$. The deposition rate of $\mathrm{AlSiO}_{\mathrm{x}}$ in rotation mode is $11.4 \mathrm{~nm} / \mathrm{min}$. The addition of $\mathrm{W}$ lead to its increase, reaching $32 \mathrm{~nm} / \mathrm{min}$ for a $\mathrm{W}$ target current of $0.75 \mathrm{~A}$. The deposition rate increases linearly with the $\mathrm{W}$ target current.
Similar analysis was performed for samples prepared with rotation speed of $7 \mathrm{rpm}$, being obtained similar deposition rates, keeping constant all the other deposition process parameters. However, the layers prepared with $7 \mathrm{rpm}$ were always less transparent than those prepared with $15 \mathrm{rpm}$. The sample prepared with $7 \mathrm{rpm}$ has a higher extinction coefficient than the one prepared with $15 \mathrm{rpm}$, which also means that the former will have a higher absorptance. This happens systematically with samples prepared with a constant $\mathrm{W}$ target current where the one prepared with a lower rotation speed has always a higher extinction coefficient. With lower rotation speed a higher $W$ thickness is deposited in each cycle and results in a sample with a higher extinction coefficient; which is also related with less $\mathrm{W}$ atoms in the $\mathrm{W}^{6+}$ and $\mathrm{W}^{5+}$ oxidation states and more in the $\mathrm{W}^{4+}$ oxidation state, which will be shown in next section. Films with tungsten atoms in the $\mathrm{W}^{6+}$ oxidation state are transparent and have a low contribution for solar radiation absorption. However, tungsten atoms in the $\mathrm{W}^{5+}$ and $\mathrm{W}^{4+}$ oxidation states already contribute substantially for solar radiation absorption. As already reported, WOy substoichiometric films become coloured for $\mathrm{y}<2.75$ (Berggren and Niklasson, 2005; Berggren et al., 2007), what was justified by the presence of $\mathrm{W}^{5+}$ and $\mathrm{W}^{4+}$ oxidation states. Thus, the films prepared with lower rotation speed have higher extinction coefficient not only due to the increasing number of tungsten atoms at $\mathrm{W}^{0}$ oxidation state but also to the higher amount of tungsten atoms in the $\mathrm{W}^{5+}$ and $\mathrm{W}^{4+}$ oxidation states.

\subsection{Oxidation state of $W$ atoms}

In order to assess the chemical composition and chemical state and bonding information of the films, two single layers were prepared and analyzed by XPS. These two layers, D1 and D2, were deposited with applied currents of $0.75 \mathrm{~A}$ and $0.5 \mathrm{~A}$ on $\mathrm{W}$ and $\mathrm{Al}$ (Si) targets, respectively, with the same argon and oxygen flow rates, but with different rotation speed, $15 \mathrm{rpm}$ for D1 and $7 \mathrm{rpm}$ for D2. This implies that a different amount of material was deposited in each turn.

Core level spectra corresponding to $\mathrm{W} 4 \mathrm{f}$ are shown in Fig. 3. The C 1s peak (not shown), appearing at $284.5 \mathrm{eV}$ binding energy, was used as a reference. Fig. 3 shows that tungsten is present in both metallic and oxidized states, for both samples; the deconvolution of the peaks demonstrates the different oxidation states of tungsten (see Table 1). The $\mathrm{W}$ 4f core level was fitted into peak doublets with a spin-orbit energy separation of $4 f_{5 / 2}-4 f_{7 / 2}=2.1 \mathrm{eV}$ and an intensity ratio $\mathrm{I}_{4 \mathrm{f5} / 2} / \mathrm{I}_{4 \mathrm{f} 7 / 2}=0.75$ (Xie et al., 2012). The respective energies of $\mathrm{W} 4 \mathrm{f}_{7 / 2}$ states are presented in Table 1 . The peaks appearing at $30.5 \mathrm{eV}$ and $30.6 \mathrm{eV}$ binding energies can be associated with metallic tungsten in D1 and D2 samples, respectively (Xie et al., 2012; Wong et al., 2000). While the peaks at $36 \mathrm{eV}, 34.8 \mathrm{eV}$ and $33.1 \mathrm{eV}$ can be ascribed to the oxidation states of $\mathrm{W}^{6+}, \mathrm{W}^{5+}$ and $\mathrm{W}^{4+}$, respectively, (Xie et al., 2012; Uppachai et al., 2014; Zhang et al., 2009; Yang et al., 2014), and the peaks at $31.6-31.7 \mathrm{eV}$ can be attributed to the intermediate $\mathrm{W}^{1+}, \mathrm{W}^{2+}$ and $\mathrm{W}^{3+}$ oxidation states commonly known as the $\mathrm{W}^{\mathrm{x}+}$ oxidation state (Xie et al., 2012; Yang et al., 2014). This $\mathrm{W}^{\mathrm{x}+}$ oxidation can be explained by tungsten ions bonded to oxygen and tungsten ions. The peak associated with $\mathrm{W}^{6+}$ oxidation state can have a small contribution coming from the $W 5 \mathrm{p}_{3 / 2}$ peak associated with $W^{0}$ oxidation state, because the binding energy of $\mathrm{W} 5 \mathrm{p}_{3 / 2}$ peak is $5.5 \mathrm{eV}$ above that of the $\mathrm{W} 4 \mathrm{f}_{7 / 2}$ peak. However, if any, should be similar for both samples.

These results show that, in both samples, about one third of $\mathrm{W}$ atoms are in the $\mathrm{W}^{0}$ oxidation state, another third in the $\mathrm{W}^{\mathrm{x}+}$ oxidation state and the last third in the $\mathrm{W}^{4+}, \mathrm{W}^{5+}$ and $\mathrm{W}^{6+}$ oxidation states. Sample D1 has $29.3 \%$ of the $\mathrm{W}$ atoms at higher oxidation 

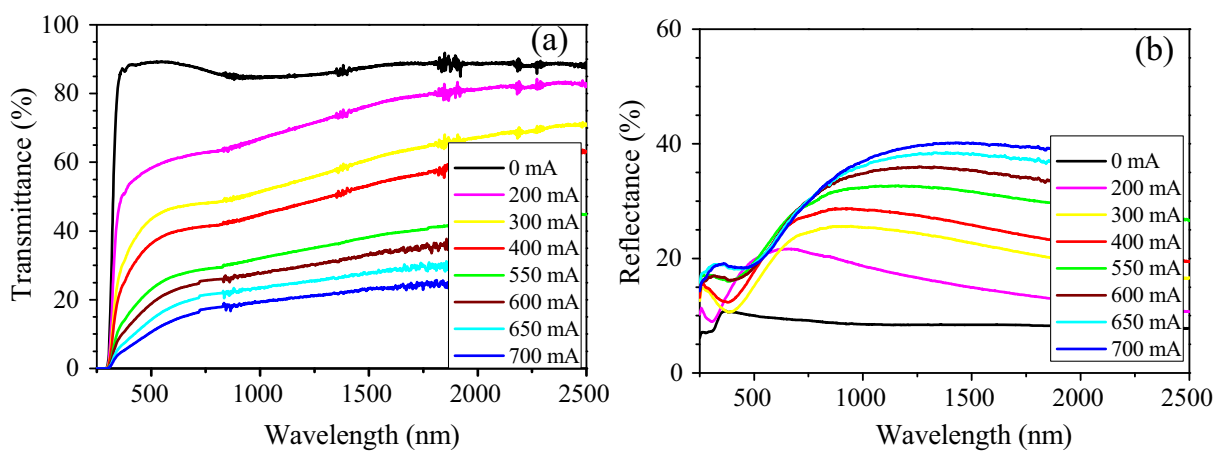

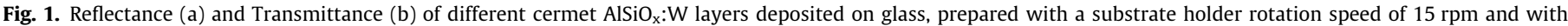
varying $\mathrm{W}$ target current.

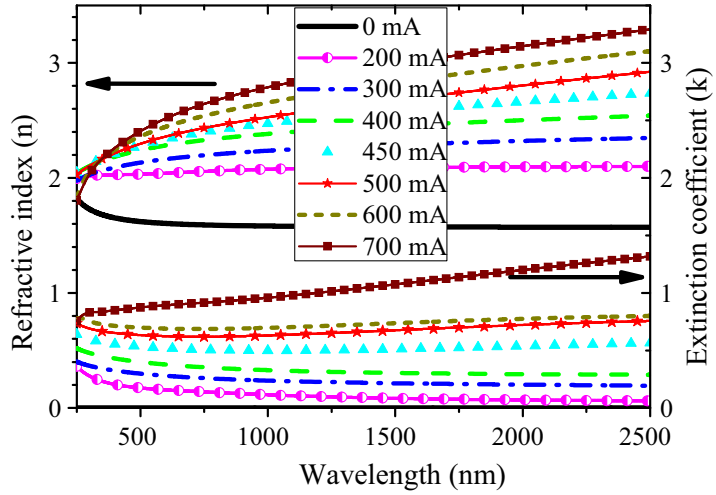

Fig. 2. Refractive index (n) and extinction coefficient $(\kappa)$ as a function of wavelength for $\mathrm{AlSiO}_{\mathrm{x}}: \mathrm{W}$ layers prepared with a substrate holder rotation speed of $15 \mathrm{rpm}$ and different $\mathrm{W}$ target currents, as indicated in the legend.

states $\left(\mathrm{W}^{6+}\right.$ and $\left.\mathrm{W}^{5+}\right)$, while the sample prepared with lower rotation speed (D2) has only $14.0 \%$ of the W atoms at those oxidation states. As it was mentioned in the previous section, this behaviour can be related with the increase in W layer thickness (in D2) deposited in each turn due to the decrease of the rotation speed.

\subsection{Structural properties}

$\mathrm{AlSiO}_{\mathrm{x}}: \mathrm{W}$ thick layers $(>700 \mathrm{~nm}$ ) were deposited and subsequently analyzed by X-ray diffraction. In Fig. 4 are represented the XRD patterns for layers prepared with a rotation speed of $15 \mathrm{rpm}$ (Fig. 4a) and of $7 \mathrm{rpm}$ (Fig. 4b) and with different $\mathrm{W}$ target currents, as indicated in the legend. The vertical scale is the same in both graphs. In all cases a broad peak is present, around $2 \theta=40^{\circ}$, which could be assigned to $(110)$ planes of bcc W lattice. The intensity of the broad peak increases with tungsten current, which is obviously correlated with the tungsten volume fraction. However, a $\sim 7^{\circ} \mathrm{FWHM}$ indicates that $\mathrm{W}, \mathrm{SiO}_{2}$ and $\mathrm{Al}_{2} \mathrm{O}_{3}$ phases are amorphous. Similar behaviour was found for $\mathrm{W}-\mathrm{Al}_{2} \mathrm{O}_{3}$ cermet layers deposited by rf sputtering (Antonaia et al., 2010). The other peaks, referred by $S$, correspond to the stainless steel substrate. The W layers, used as infrared back reflectors, are polycrystalline, with a bcc structure and [110] preferred crystallographic direction.

\subsection{Development of the optical stacks}

A set of $\mathrm{AlSiO}_{\mathrm{x}}: \mathrm{W}$ layers for each rotation speed ( 7 and $15 \mathrm{rpm}$ ) with varying the $\mathrm{W}$ target current was used to elaborate the optimization of the optical stack. These optical constants were used to design the structure of the multilayers simulating its reflectance

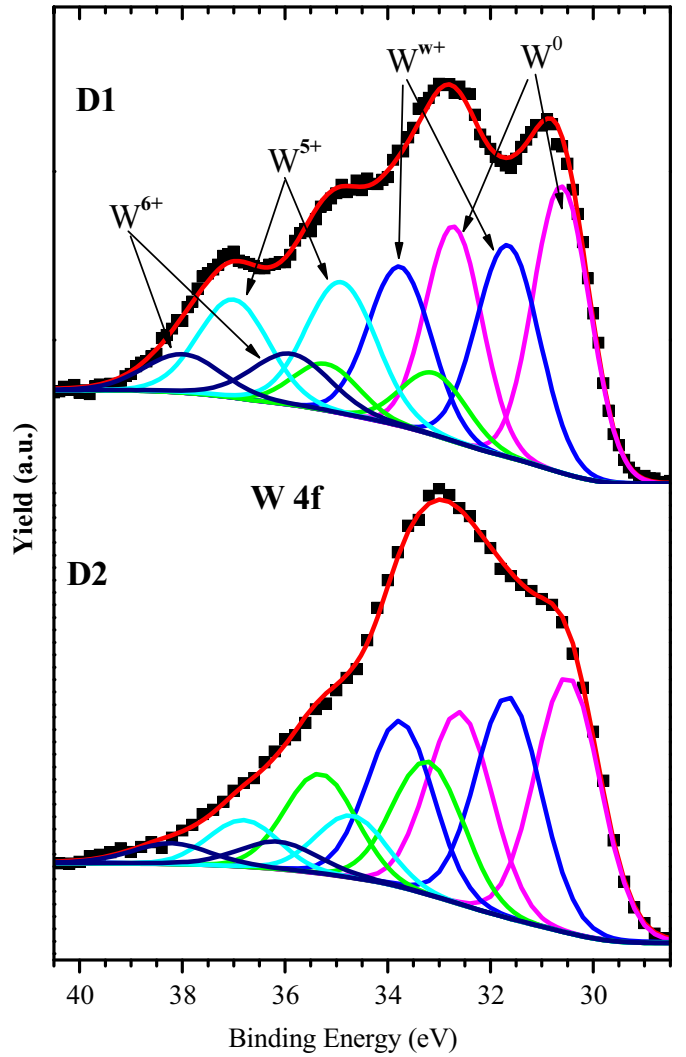

Fig. 3. XPS spectra of $\mathrm{W} 4 \mathrm{f}$ electrons for analyzed samples. D1 was prepared with $15 \mathrm{rpm}$ and D2 with $7 \mathrm{rpm}$.

varying the materials and respective thicknesses. The $\mathrm{W}$ layer, with a thickness of about $150 \mathrm{~nm}$, was already used and published (Rebouta et al., 2015; Rebouta et al., 2015), providing good results; the same $\mathrm{W}$ layer was employed in all stacks. The multilayers were built with 4 layers, as schematically represented in Fig. 5.

From the optimization procedure, the deposition parameters were selected for different layers, such as $\mathrm{W}$ target current and respective layer thicknesses, which defines the deposition time. In Table 2 are presented the parameters associated with the single layers used in each multilayer coating stack, being identified by the W target current, the respective thicknesses and deposition times for the three outermost layers. The first three coatings (A, B and C) were prepared with a rotation speed mode of $15 \mathrm{rpm}$, while in the fourth (sample D) the rotation speed was set to $7 \mathrm{rpm}$. The spectral reflectance of these coatings is shown in Fig. 6. The solar absorptance and thermal emittance (at $400^{\circ} \mathrm{C}$ ) are shown in the 
Table 1

Identification of W $4 \mathrm{f}$ core level binding energies from analyzed samples shown in Fig. 3.

\begin{tabular}{|c|c|c|c|c|c|}
\hline \multirow{2}{*}{$\begin{array}{l}\text { Sample } \\
\text { Core level }\end{array}$} & \multicolumn{2}{|l|}{ D1 } & \multicolumn{2}{|l|}{ D2 } & \multirow[b]{2}{*}{ Oxidation state } \\
\hline & $\mathrm{BE}(\mathrm{eV})$ & Peak area & $\mathrm{BE}(\mathrm{eV})$ & Peak area & \\
\hline \multirow[t]{5}{*}{$\mathrm{W} 4 \mathrm{f}_{7 / 2}$} & 30.6 & $33.9 \%$ & 30.5 & $35.2 \%$ & $\mathrm{~W}^{0}$ \\
\hline & 31.7 & $28.2 \%$ & 31.6 & $31.2 \%$ & $\mathrm{~W}^{\mathrm{x}+}$ \\
\hline & 33.1 & $8.6 \%$ & 33.2 & $19.6 \%$ & $\mathrm{~W}^{4+}$ \\
\hline & 34.9 & $20.3 \%$ & 34.6 & $9.1 \%$ & $\mathrm{~W}^{5+}$ \\
\hline & 35.9 & $9.0 \%$ & 36.3 & $4.9 \%$ & $\mathrm{w}^{6+}$ \\
\hline
\end{tabular}

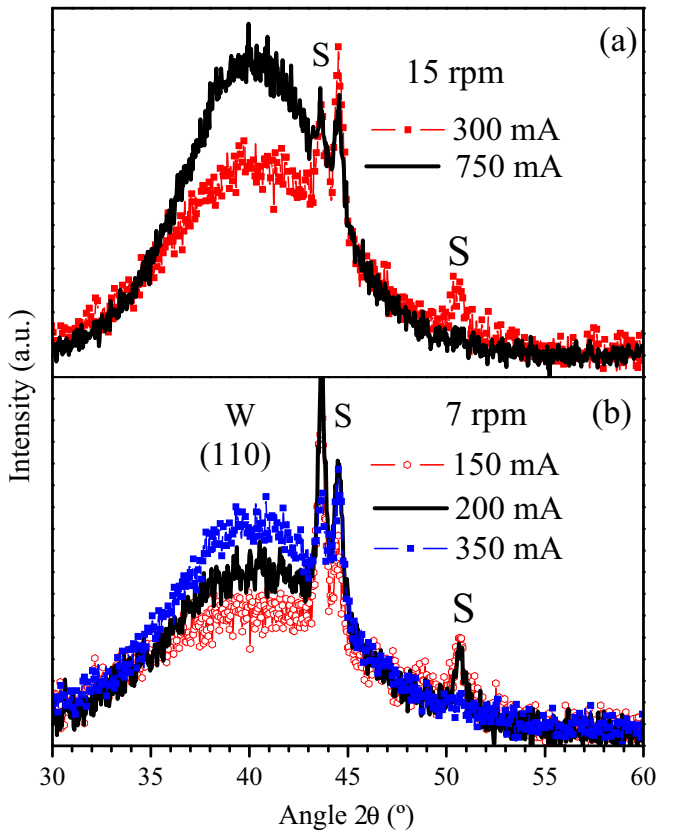

Fig. 4. XRD diffractograms performed with an incidence angle of $3^{\circ}$ for $\mathrm{AlSiO}_{\mathrm{x}}: \mathrm{W}$ single layers prepared with different $\mathrm{W}$ target currents (indicated in the legend) and rotation speeds: (a) $15 \mathrm{rpm}$ (b) $7 \mathrm{rpm}$. The peaks referred by $\mathrm{S}$, correspond to the stainless steel substrate.

\begin{tabular}{|c|}
\hline $\mathrm{AlSiO}_{\mathrm{x}}$ \\
\hline $\mathrm{AlSiO}_{\mathrm{x}}: \mathrm{W}(\mathrm{LA})$ \\
\hline $\mathrm{AlSiO}_{\mathrm{x}}: \mathrm{W}(\mathrm{HA})$ \\
\hline $\mathrm{W}(\sim 150 \mathrm{~nm})$ \\
\hline polished stainless steel \\
\hline
\end{tabular}

Fig. 5. Sketch of multilayer coatings based on $\mathrm{AlSiO}_{\mathrm{x}}: \mathrm{W}$ cermets.

Table 2

Process parameters of single layers used in the multilayers, including $\mathrm{W}$ target current, layer thickness and deposition time.

\begin{tabular}{llll}
\hline Sample & W target current $(\mathrm{mA})$ & Layer thickness $(\mathrm{nm})$ & Deposition time $(\mathrm{s})$ \\
\hline A & $750 / 200 / 0$ & $69 / 30 / 76$ & $130 / 105 / 400$ \\
B & $750 / 300 / 0$ & $58 / 33 / 69$ & $110 / 90 / 363$ \\
C & $750 / 300 / 0$ & $53 / 33 / 62$ & $100 / 90 / 326$ \\
D & $350 / 200 / 0$ & $57 / 30 / 90$ & $149 / 83 / 474$ \\
\hline
\end{tabular}

legend of this figure. The solar absorptance is higher for sample A, being related with the higher thicknesses of HA and LA layers, having this sample also a higher emissivity (at $400^{\circ} \mathrm{C}$ ). In sample $\mathrm{D}$, the step on the wavelength scale is shifted to lower wavelengths,

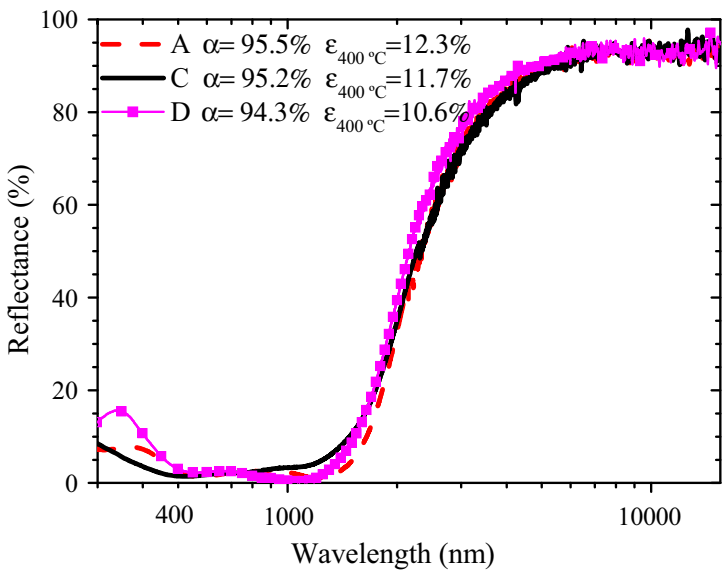

Fig. 6. Reflectance of different $\mathrm{AlSiO}_{\mathrm{x}}: \mathrm{W}$ absorber coatings described in Table 2 . The absorptance and emissivity at $400{ }^{\circ} \mathrm{C}$ are also indicated in the legend.

which impacts in a reduction of both solar absorptance and emissivity at $400{ }^{\circ} \mathrm{C}$.

The different coatings, deposited on polished stainless steel substrates, were analyzed by SEM. In Fig. 7 are shown the micrographs obtained for samples B (Fig. 7a) and D (Fig. 7b), with the indication of the constituent layers of the optical stack and the respective thicknesses. In all cases, the first layer (W) shows a morphology consistent with a columnar growth. The remaining layers reveal a featureless morphology, which agrees with the amorphous structure obtained from the XRD analyses, as shown in Fig. 4 for $\mathrm{AlSiO}_{\mathrm{x}}: \mathrm{W}$ layers. The top layer is the $\mathrm{AlSiO}_{\mathrm{x}}$ antireflection layer. The contrast difference between the two cermet layers in the SEM micrographs is very small, with a slight distinction between them in Fig. 7a, but indistinguishable in Fig. 7b. This behaviour is related with metal volume fraction in the different layers. In sample $\mathrm{B}$, the two cermet layers were deposited applying $\mathrm{W}$ target currents of 0.75 and $0.3 \mathrm{~A}$, respectively, while in sample $\mathrm{D}$ the two cermet layers were deposited with $\mathrm{W}$ target currents of 0.35 and $0.2 \mathrm{~A}$, although with different rotation speeds, $15 \mathrm{rpm}$ and $7 \mathrm{rpm}$, respectively. The thicknesses are similar to those mentioned in Table 2, within a deviation of $10 \%$.

The featureless morphology obtained for cermet and antireflection layers is similar to the obtained for the coating based on $\mathrm{SiO}_{2}$ : W layer cermet (Wäckelgård et al., 2015), but contrasts with what was obtained for $\mathrm{SiO}_{2}$ :Mo layer cermets (Esposito et al., 2009). In that case the two cermet layers and the antireflection layer appear to continue the columnar growth of the molybdenum layer in spite of an amorphous structure.

These samples were analyzed by XRD and a similar pattern was obtained for all as-deposited samples. The pattern measured for sample D is shown in the Fig. 8 . The peaks addressed to tungsten are related with $\mathrm{W}$ layer, which is polycrystalline. As expected, from the measurements of single layers, the other layers are XRD amorphous. The small peaks marked with $\mathrm{S}\left(2 \theta \approx 43.6^{\circ}, 44.5^{\circ}\right.$ and $50.7^{\circ}$ ) are ascribed to the 304 stainless steel substrate 

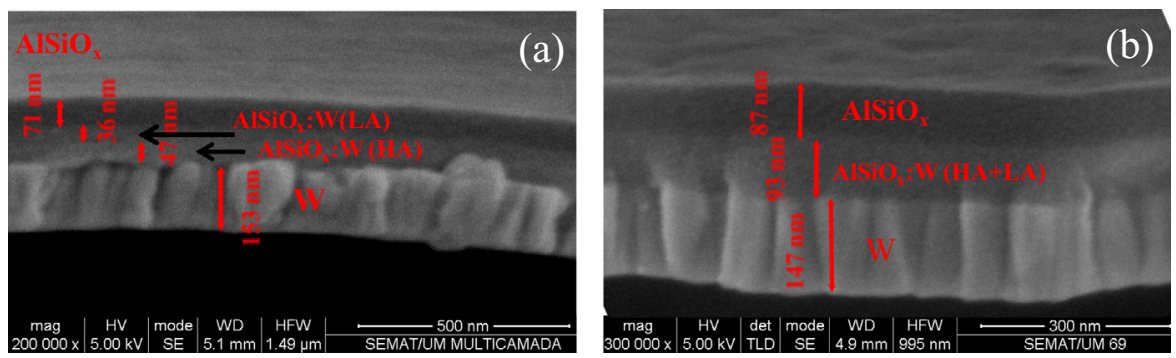

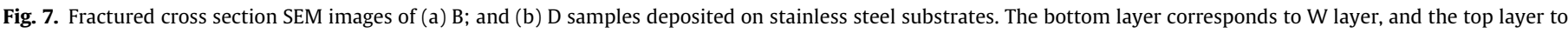
the antireflection layer. The intermediate layer corresponds to the double layer structure (HA and LA layers).

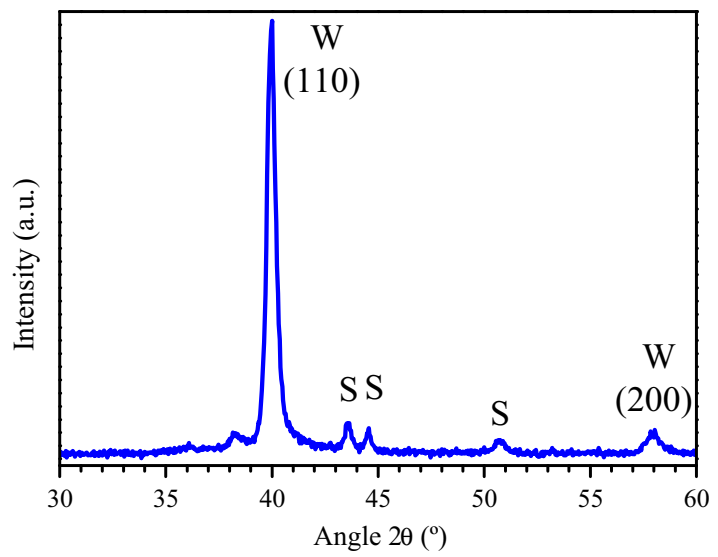

Fig. 8. X-ray diffraction pattern of as-deposited sample D. The measurements were performed with a fixed grazing incidence angle of $3^{\circ} . \mathrm{S}$ indicates the peaks associated with stainless steel substrate.

(Rebouta et al., 2015), reporting to fcc-austenite (111), bccmartensite (110) and austenite (200) phases, respectively (Peng et al., 2016). The very small peak appearing at $2 \theta \approx 36^{\circ}$ can be eventually related to (200) diffraction planes from $\beta$-W (Sibin et al., 2015). The small peak at $2 \theta \approx 38.3^{\circ}$ did not appear in the XRD diffractograms of $\mathrm{W}$ layer and antireflection layer (Rebouta et al., 2015), which means it must be related with the cermet layers, but cannot be clearly addressed to a tungsten oxide phase or to aluminium oxide phase.

\subsection{Thermal stability}

These optical stacks were subjected to a thermal annealing in air at $450{ }^{\circ} \mathrm{C}$ and in vacuum at $580{ }^{\circ} \mathrm{C}$. In Fig. 9 the reflectance of representative coatings in their as-deposited state and after the thermal treatments in air (Fig. 9a and b) and in vacuum (Fig. 9c) is presented. The legends indicate the solar absorptance and thermal emittance (calculated at $400^{\circ} \mathrm{C}$ ) for different situations.

The reflectance profile of samples $\mathrm{A}, \mathrm{B}$ and $\mathrm{C}$ revealed minor changes after the annealing in air at $450{ }^{\circ} \mathrm{C}$, similar to those shown in Fig. 9a. The changes in sample D were slightly higher, as shown in Fig. 9b. The change in the reflectance profile happened in the first annealing step, of $200 \mathrm{~h}$, and in the following annealing steps only minor changes were seen. In terms of annealing in vacuum at $580^{\circ} \mathrm{C}$, the samples $\mathrm{A}, \mathrm{B}$ and $\mathrm{C}$ had a similar behaviour, as the one represented in the Fig. 9c, showing very small changes in the reflectance profile after the first annealing step, which induced a small decrease in solar absorptance, but without significant changes after the additional steps, although with small changes in the solar absorptance values. Changes in first annealing steps followed by steps without significant changes, with very good thermal stability, were also reported by other authors in coatings based on $\mathrm{Al}_{2} \mathrm{O}_{3}: \mathrm{W}$ (Antonaia et al., 2010) and $\mathrm{SiO}_{2}$ :Mo (Esposito et al., 2009) cermets. In these reports the changes were seen for the initial annealing steps within 7 days, which is within the first annealing step of about $200 \mathrm{~h}$, used in our tests.

In Fig. 10 are shown the solar absorptance and thermal emittance (calculated at $400^{\circ} \mathrm{C}$ ) values as a function of the annealing time, for annealing in air at $450{ }^{\circ} \mathrm{C}$ (Fig. 10a) and in vacuum at $580^{\circ} \mathrm{C}$ (Fig. 10b). The solar absorptance value is maintained after 33 days in air, at $450{ }^{\circ} \mathrm{C}$. The thermal emittance was measured in as-deposited samples and after all annealing steps. Several samples revealed a small decrease in emissivity, and only the sample D showed an increase of thermal emittance. This shows that these coatings have very good thermal stability and oxidation resistance. Similar samples were also annealed in air at $400^{\circ} \mathrm{C}$, with identical results.

Some reasons can influence the latter behaviour. Both silicon and aluminium oxides are known to have good properties as diffusion barriers and also good thermal stability. Additionally, the film structure is predominantly amorphous (except for the $\mathrm{W}$ layer), as confirmed by XRD. This is a consequence of the local chemical bonding effects in the materials, which is important for avoiding the diffusivity paths when intergranular phases are present, which improves the performance of oxide layers as oxygen diffusion barrier layers. Finally, the surface finishing also influences this behaviour. The low substrate roughness increases the thin film surface coverage and eventually decreases the interfacial porosity, what improves the thermal stability. The emissivity decrease after the thermal annealing in vacuum was also reported in other cases, for example in $\mathrm{SiO}_{2}$ :W cermet layers (Wäckelgård et al., 2015) with thermal annealing in vacuum at $350^{\circ} \mathrm{C}$. The deterioration of the $\mathrm{W}$ layer would lead to an increase of the emissivity. Thus, the fact that the emissivity decreases should be related with changes in the outermost layers. Additionally it was found by XPS that part of the Si atoms in the antireflection AlSiOx layer were not completely oxidized and the first annealing step was enough to oxidize these $\mathrm{Si}$ atoms. This oxidation would be responsible for a small increase of the transmittance in near infrared wavelength range (and a subsequent decrease in absorption) which can lead to a small decrease in the emissivity.

XRD diffractograms of annealed samples and as deposited samples are shown in Fig. 11. The XRD patterns of annealed samples A (Fig. 11a) and B (Fig. 11b) show small changes when compared with those measured in as-deposited state. The main changes can be seen in the diffraction peaks located at $2 \theta \approx 43.6^{\circ}, 44.5^{\circ}$ and $50.7^{\circ}$, which are the peaks associated with SS substrate. A small increase is registered in the intensity of (110) W peak, which can be attributed to some degree of recrystallization in the polycrystalline $\mathrm{W}$ layer.

In order to assess any diffusion of metallic atoms towards the surface, three multilayer coatings from same run (sample D) were analyzed by XPS. One was in as deposited state, a second was 

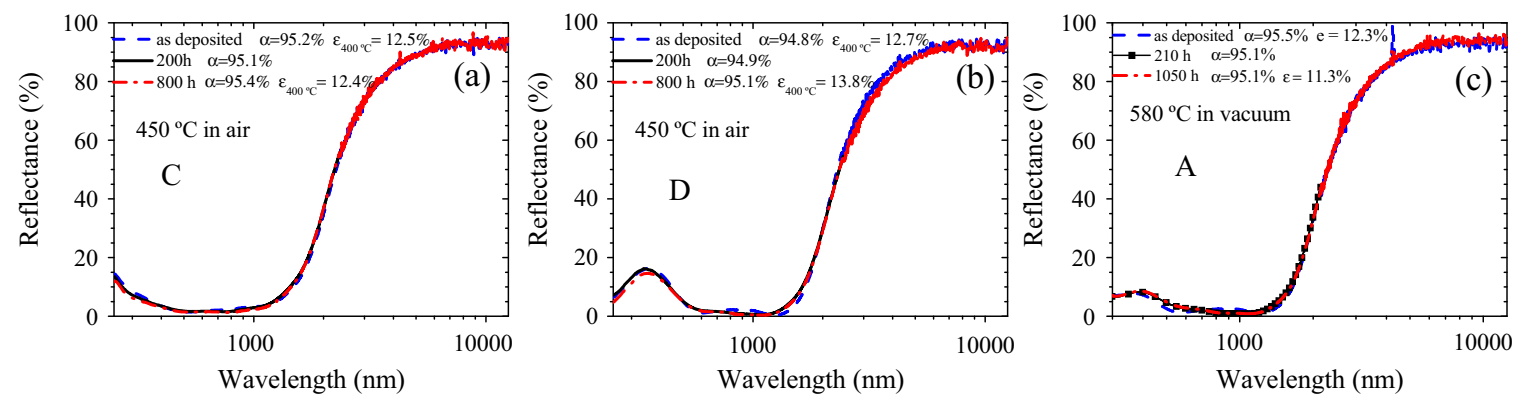

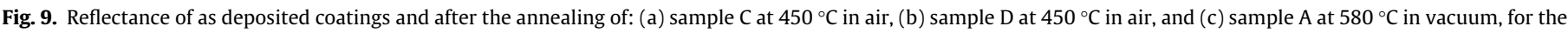
periods indicated in the legend. The solar absorptance and the thermal emittance (calculated at $400{ }^{\circ} \mathrm{C}$ ) after each annealing step are also indicated in the legend.
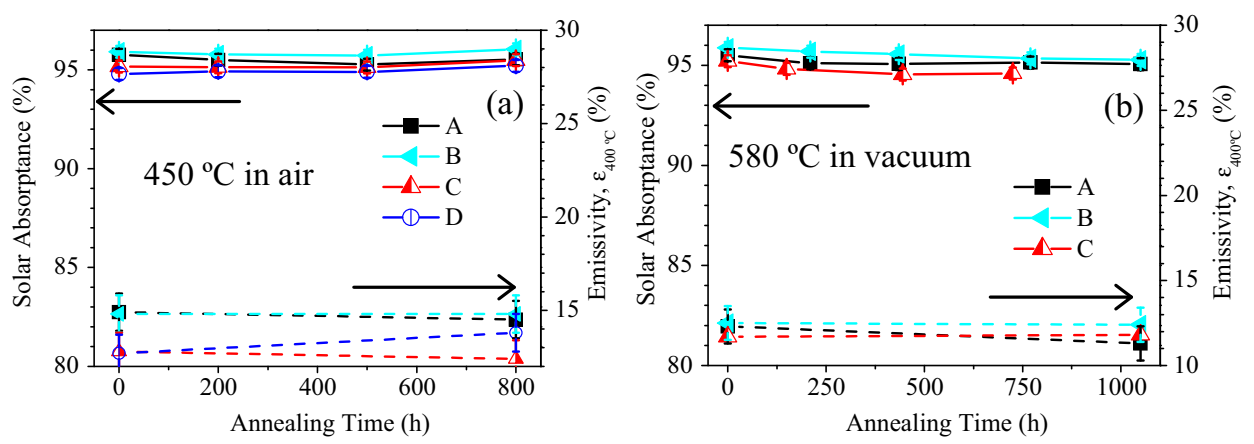

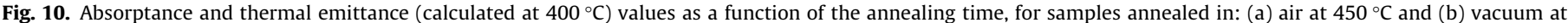
$580^{\circ} \mathrm{C}$. The lines are solely introduced to guide the eyes.

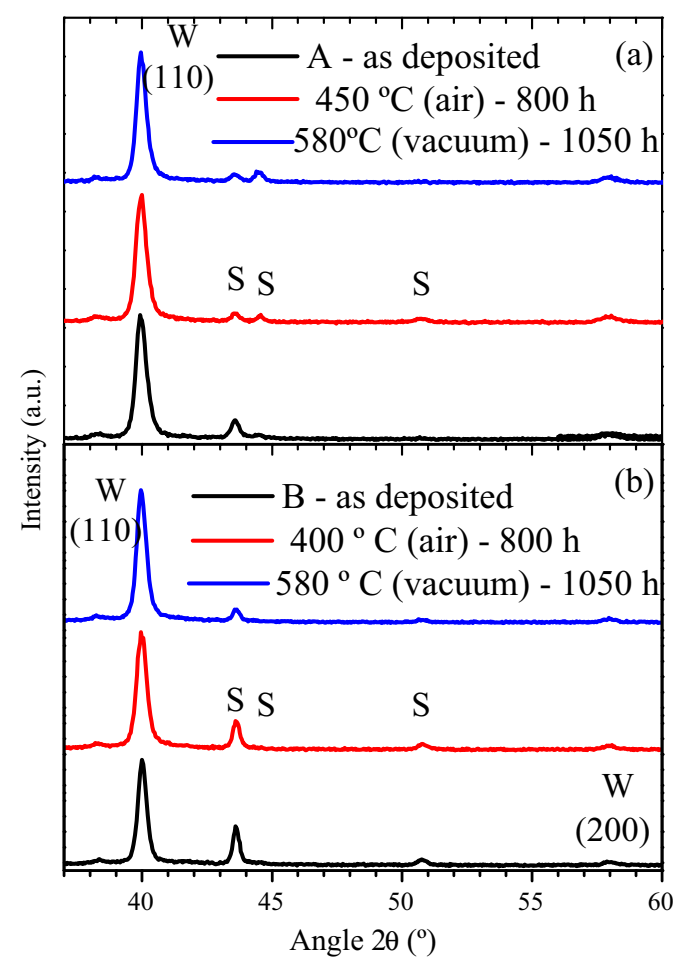

Fig. 11. X-ray patterns of samples A (a) and B (b) measured in as deposited state and after thermal treatments, as indicated in the figure. The legend indicates the diffractograms from bottom to top.

annealed in air at $400{ }^{\circ} \mathrm{C}$ and the third was annealed in vacuum at $580^{\circ} \mathrm{C}$, both during $50 \mathrm{~h}$. The antireflection layer, $\mathrm{AlSiO}_{\mathrm{x}}$, has a thickness of about $90 \mathrm{~nm}$, which means the analysis was done within this surface layer. Core level spectra corresponding to Al 2p, Si 2p, $\mathrm{O} 1 \mathrm{~s}$ and $\mathrm{W}$ 4f are shown in Fig. 12 and peak data extracted from this fit are presented in Table 3. The $C 1 \mathrm{~s}$ peak (not shown) was used as a reference. Fig. 12a shows Al 2p XPS core level spectra, and the results show that $\mathrm{Al}$ is present in oxidized ( $\sim 74.8 \mathrm{eV}, \sim 75.7 \mathrm{eV}$ and $\sim 76.5 \mathrm{eV}$ ) states, which binding energies correspond to $\mathrm{Al}_{2} \mathrm{O}_{3}$ and $\mathrm{Al}(\mathrm{OH})_{3}$ compounds (Li et al., 1997). Fig. 12b shows $\mathrm{Si} 2$ p core level spectra. The as deposited sample revealed a small peak located at $\sim 100 \mathrm{eV}$, which can be ascribed to the $\mathrm{Si}^{+}$oxidation state (Shioji et al., 2004), showing that about $4 \%$ of the Si atoms are not oxidized. This peak disappeared after the thermal annealing, what can justify a small change in the optical properties of the coating. The remaining peaks, located at 102$104 \mathrm{eV}$, can be addressed to $\mathrm{Si}^{3+}$ and $\mathrm{Si}^{4+}$ oxidation states or to oxidized Si (Shioji et al., 2004). Oxidation was also reported in similar coatings based on $\mathrm{SiO}_{2}: \mathrm{W}$ cermet layers (Wäckelgård et al., 2015), where was measured a small increase of oxygen amount together with a decrease of the $\mathrm{H}$ content in the surface layer.

The core level spectra corresponding to $\mathrm{W} 4 \mathrm{f}$ electrons are shown in Fig. 12c. The as deposited sample and the one annealed at $580{ }^{\circ} \mathrm{C}$ in vacuum did not show any peak, in opposition to what happened with sample annealed in air at $400^{\circ} \mathrm{C}$. The peaks show the presence of $\mathrm{WO}_{3}$ in the surface of the antireflection layer. This represents only 0.4 at.\% of this layer. More experiments would be needed to clarify this point, because this behaviour cannot be explained only by $\mathrm{W}$ diffusion. The diffusion is a temperature dependent process, and at $580{ }^{\circ} \mathrm{C}$ would be more favourable as compared to $400^{\circ} \mathrm{C}$. However, the justification for this behaviour can be related not only with the annealing temperature but also with the annealing atmosphere. Under vacuum it mainly occurs outward diffusion processes, and SiAlOx is known as good barrier diffusion layer. Under air we have additionally oxidation processes due to oxygen inward diffusion, which can induce volume increase and interface degradation. This can also be related with incomplete 

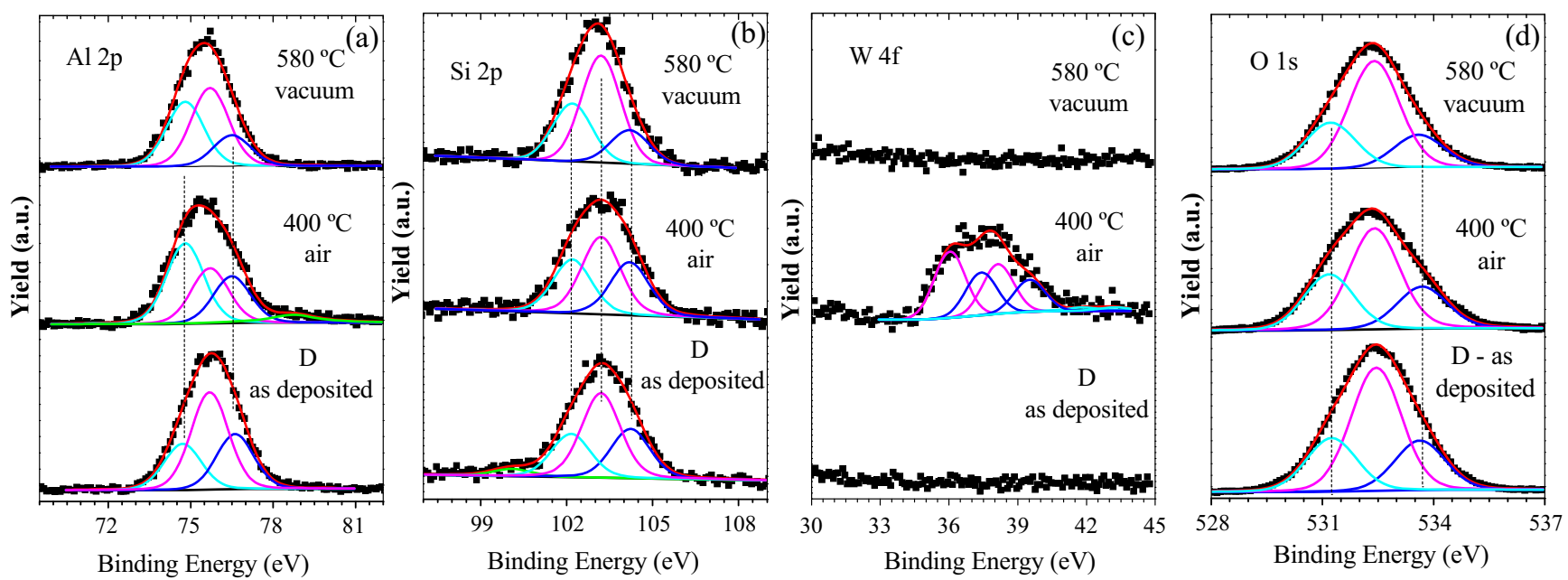

Fig. 12. XPS spectra of: (a) Al 2p, (b) Si 2p, (c) W $4 \mathrm{f}$ and (d) $\mathrm{O} 1$ s electrons for analyzed D samples.

Table 3

Identification of core level binding energies of $\mathrm{Al} 2 \mathrm{p}$, Si 2p, W4f and $\mathrm{O} 1 \mathrm{~s}$ for as-deposited samples and annealed at $400{ }^{\circ} \mathrm{C}$ in air and at $580{ }^{\circ} \mathrm{C}$ in vacuum.

\begin{tabular}{|c|c|c|c|c|c|c|c|}
\hline & \multicolumn{2}{|c|}{ As-deposited } & \multicolumn{2}{|c|}{$400{ }^{\circ} \mathrm{C}$ air } & \multicolumn{2}{|c|}{$580^{\circ} \mathrm{C}$ vacuum } & \multirow[t]{2}{*}{ Oxidation state } \\
\hline & $\mathrm{BE}(\mathrm{eV})$ & Peak area (\%) & $\mathrm{BE}(\mathrm{eV})$ & Peak area (\%) & $\mathrm{BE}(\mathrm{eV})$ & Peak area (\%) & \\
\hline \multirow[t]{4}{*}{$\mathrm{Al} \mathrm{2p}$} & 74.7 & 23.2 & 74.8 & 41.0 & 74.8 & 37.3 & $\mathrm{Al}^{3+}$ \\
\hline & 75.7 & 49.0 & 75.7 & 28.1 & 75.7 & 45.0 & $\mathrm{Al}^{3+} \mathrm{Al}_{2} \mathrm{O}_{3}$ \\
\hline & 76.6 & 27.7 & 76.5 & 23.8 & 76.5 & 17.7 & $\mathrm{Al}^{3+} \mathrm{Al}(\mathrm{OH})_{3}$ \\
\hline & - & - & 78.7 & 7.1 & - & - & \\
\hline \multirow[t]{4}{*}{ Si $2 p$} & 100.0 & 4.0 & - & - & - & - & $\mathrm{Si}^{+}$ \\
\hline & 102.2 & 23.5 & 102.2 & 29.3 & 102.2 & 29.2 & $\mathrm{Si}^{2+}$ \\
\hline & 103.2 & 45.8 & 103.2 & 41.9 & 103.2 & 53.9 & $\mathrm{Si}^{3+}$ \\
\hline & 104.2 & 26.8 & 104.2 & 28.8 & 104.2 & 16.9 & $\mathrm{Si}^{4+}$ \\
\hline \multirow[t]{2}{*}{$W 4 f_{7 / 2}$} & - & - & 36.0 & 60.7 & - & - & $W^{6+}$ \\
\hline & - & - & 37.4 & 39.3 & - & - & $\mathrm{W}^{6+}$ \\
\hline \multirow[t]{3}{*}{$\mathrm{O} 1 \mathrm{~s}$} & 531.2 & 23.7 & 531.2 & 27.5 & 531.2 & 24.9 & \\
\hline & 532.5 & 54.5 & 532.4 & 51.2 & 532.4 & 57.6 & \\
\hline & 533.6 & 21.9 & 533.7 & 21.3 & 533.6 & 17.5 & \\
\hline
\end{tabular}

surface coverage by the oxide layer due the presence of some scratches originated by the mechanical surface polishing prior to deposition. The $\mathrm{O} 1 \mathrm{~s}$ peaks, $\sim 531.2$ and $\sim 532.5 \mathrm{eV}$, (shown in Fig. $12 \mathrm{~d}$ ) can be addressed to $\mathrm{C}=\mathrm{O}$ groups and $\mathrm{C}-\mathrm{OH}$ and/or C-O-C groups, respectively (Yue et al., 1999). The peak located at $\sim 533.6 \mathrm{eV}$ can be ascribed to $\mathrm{SiO}_{2}$.

Rutherford Backscattering was used to study the possible W diffusion to sample surface with the annealing. Experimental RBS spectrum of the sample annealed at $400{ }^{\circ} \mathrm{C}$ in air is displayed in Fig. 13. RBS spectra were fitted with IBA DataFurnace (NDF) software (Pascual-Izarra et al., 2006). In order to improve the depth resolution, the spectrum was taken with the sample tilted $20^{\circ}$, as shown in insert of Fig. 13, and with detected backscattered particles making $60^{\circ}$ with the normal of sample surface. No significant differences were seen with the other two samples, the as deposited and the one annealed in vacuum. Since the outermost layer of the multilayer is the AlSiOx layer, the backscattered signal from the W in the first AlSiOx:W layer is shifted to lower energies, as shown in Fig. 13. In this layer was not found any W content (within the error of the measurement). The minimum amount that can be detected in this geometry is 0.2 at.\%, when the signal can be distinguished from the pileup background. The W content of the AlSiOx:W(LA) layer is 14.2 at.\%, while for the AlSiOx:W(HA) layer is 19.9 at.\%.

AFM was used for studying surface roughness of the same three samples from same run, one in as deposited state, a second annealed in air at $400^{\circ} \mathrm{C}$ and the third annealed in vacuum at

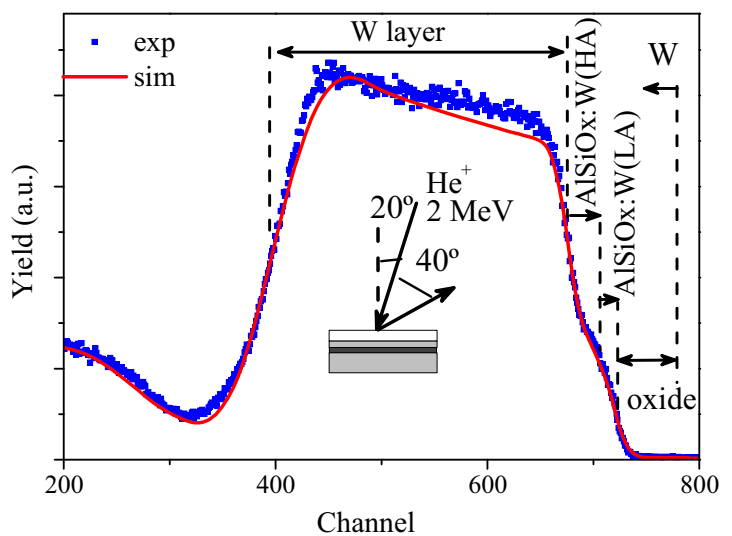

Fig. 13. RBS spectrum of $D$ sample after annealing at $400{ }^{\circ} \mathrm{C}$ in air.

$580^{\circ} \mathrm{C}$. The surface roughness $\mathrm{R}_{\mathrm{a}}$ was averaged from three $5 \times 5 \mu \mathrm{m}^{2}$ scans, and the AFM micrographs of the as-deposited and annealed films are presented in Fig. 14. Some scratches can be seen, which are due to the mechanical surface polishing prior the deposition. The surface morphology indicates featureless grain growth indicating no clear grain formation, which is in agreement with the amorphous structure. With the annealing, a slight increase of surface roughness was found, changing from $R_{a}=1.9$ - 


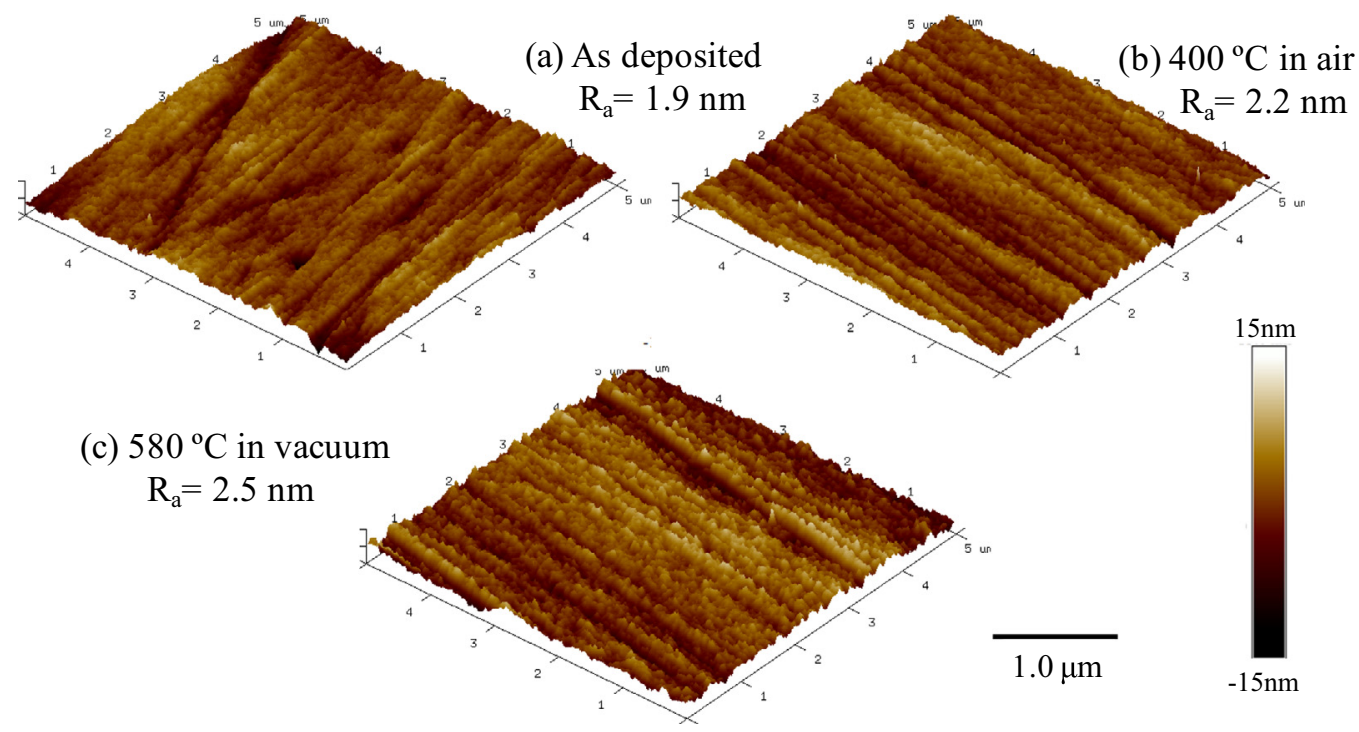

Fig. 14. Surface roughness imaged by AFM $\left(5 \times 5 \mu \mathrm{m}^{2}\right)$ of: (a) as deposited coating; (b) after the annealing at $400{ }^{\circ} \mathrm{C}$ in air; (c) after the annealing at $580{ }^{\circ} \mathrm{C}$ in vacuum.

$\mathrm{nm}$ for the as deposited state to $2.2 \mathrm{~nm}$ after the annealing in air, and $2.5 \mathrm{~nm}$ after the annealing in vacuum. This variation is certainly associated with small spike formation, mainly on scratch edges, and more evident after the annealing at $580{ }^{\circ} \mathrm{C}$ in vacuum. This behaviour, associated with the oxidation of antireflection layer, shown in Fig. 12, can be the origin of the small changes in optical properties, and shown in Figs. 9 and 10.

\section{Conclusions}

Design and fabrication of a four-layer coating based on the $\mathrm{AlSiO}_{\mathrm{x}}: \mathrm{W}$ cermet layers for selective absorption of solar radiation was performed. The X-ray diffractograms of $\mathrm{AlSiO}_{\mathrm{x}}$ :W layers indicated that both, $\mathrm{W}$ and $\mathrm{AlSiO}_{\mathrm{x}}$, are amorphous. The dielectric function and the thickness of the different layers deposited on glass were calculated through the modelling of the experimental transmittance and reflectance curves by a commercial optical simulation program (SCOUT). The optical constants of the single layers were then used to construct the four layer stack. The as deposited optical stack, $\mathrm{W} / \mathrm{AlSiO}_{\mathrm{x}}: \mathrm{W}(\mathrm{HA}) / \mathrm{AlSiO}_{\mathrm{x}}: \mathrm{W}(\mathrm{LA}) / \mathrm{AlSiO}_{\mathrm{x}}$, revealed a solar absorptance of $94-95.5 \%$ and emissivities of $8-9 \%$ (at $100{ }^{\circ} \mathrm{C}$ ) and $10-14 \%$ (at $400{ }^{\circ} \mathrm{C}$ ). XPS results showed that the high metal volume fraction cermet layer, $\mathrm{AlSiO}_{\mathrm{x}}: \mathrm{W}(\mathrm{HA})$, of samples $\mathrm{A}$, $B$ and $C$ have about one third of $W$ atoms in the $W^{0}$ oxidation state, another third in the $\mathrm{W}^{\mathrm{x}+}$ oxidation state and the last third in the $\mathrm{W}^{4+}, \mathrm{W}^{5+}$ and $\mathrm{W}^{6+}$ oxidation states. The samples were subjected to a thermal annealing at $450{ }^{\circ} \mathrm{C}$ in air, and at $580{ }^{\circ} \mathrm{C}$, in vacuum, and the tandem structure showed very good thermal stability. A small change in the reflectance profile was found after the first annealing step, but no significant changes were found after the additional steps.

It was found that the as deposited $\mathrm{AlSiO}_{\mathrm{x}}$ antireflection layer has about $4 \%$ of the $\mathrm{Si}$ atoms in the $\mathrm{Si}^{+}$oxidation state, which were oxidized during the annealing steps. This can be one of the reasons for a small change during the first annealing steps.

Samples annealed in air at $400{ }^{\circ} \mathrm{C}$ revealed the presence of $\mathrm{W}$ in the surface of the antireflection layer, whereas the as-deposited and annealed at $580^{\circ} \mathrm{C}$ in vacuum samples did not. In a long term and under air annealing, this behaviour would have impact on the optical properties of the absorber. In order to avoid this, the absorbers are under vacuum, which improves its durability.

\section{Acknowledgements}

The authors acknowledge the support of the Portuguese Foundation for Science and Technology (FCT) in the framework of the Strategic Funding UID/FIS/04650/2013. The authors are also grateful to the financial support of FCT, POCI and PORL operational programs through the project POCI-01-0145-FEDER-016907 (PTDC) CTM-ENE/2882/2014), co-financed by European community fund FEDER. The authors also acknowledge OIST-Japan for using the XPS-Kratos.

\section{References}

An, L., Ali, S.T., Søndergaard, T., Nørgaard, J., Tsao, Y., Pedersen, K., 2015. Optimization of TiAlN/TiAlON/ $\mathrm{Si}_{3} \mathrm{~N}_{4}$ solar absorber coatings. Sol. Energy 118, 410-418.

Antonaia, A., Castaldo, A., Addonizio, M.L., Esposito, S., 2010. Stability of W- $\mathrm{Al}_{2} \mathrm{O}_{3}$ cermet based solar coating for receiver tube operating at high temperature. Sol. Energy Mater. Sol. Cells 94, 1604-1611.

Archimede Solar Energy, (http://www.archimedesolarenergy.it/parabolic_trough_ archimede.htm)

Barshilia, H.C. Selvakumar, N., Rajam, KS. Sridhara Rao, D.V Muraleedharan, K. 2008. Deposition and characterization of TiAIN/TiAlON/Si3N4 tandem absorbers prepared using reactive direct current magnetron sputtering. Thin Solid Films $516,6071-6078$.

Barshilia, Harish C., Selvakumar, N., Rajam, K.S., Biswas, A., 2008. Spectrally selective NbAIN/NbAlON/ Si3N4 tandem absorber for high-temperature solar applications. Sol. Energy Mater. Sol. Cells 92, 495-504.

Berggren, L., Niklasson, G.A., 2005. Influence of sputtering conditions on the solar and luminous optical properties of amorphous $\mathrm{Li}_{x} \mathrm{Wo}_{y}$ thin films. Sol. Energy Mater. Sol. Cells 85, 573-586.

Berggren, L. Jonsson, J.C. Niklasson, G.A., 2007. Optical absorption in lithiated tungsten oxide thin films: experiment and theory. J. Appl. Phys. 102, 083538.

Bogaerts, W.F., Lampert, C.M., 1983. Materials for photothermal solar energy conversion. J. Mater. Sci. 18, 2847-2875.

Boström, T., Valizadeh, S., Luc, J., Jensen, J., Westin, G., Wäckelgård, E., 2011. Structure and morphology of nickel-alumina/silica solar thermal selective absorbers. J. Non-Cryst. Solids 357, 1370-1375.

Bruggeman, D.A.G. 1935. Calculation of the various physical constants of heterogeneous constants. Ann. Phys. 24, 636-664.

Burkholder, F., Kutscher C., 2009. Heat Loss Testing of Schott́s 2008 PTR70 Parabolic Trough Receiver, NREL Tecnical Report NREL/TP-550-45633.

Cao, F., Kraemer, D., Sun, T., Lan, Y. Chen, G., Ren, Z., 2015. Enhanced thermal stability of W-Ni-Al2O3 Cermet based spectrally selective solar absorbers with tungsten infrared reflectors. Adv. Energy Mater. 5, 1401042.

Céspedes, E. Wirz, M., Sánchez-Garcia, J.A., Alvarez-Fraga, L., Escobar-Galindo, R. Prieto, C., 2014. Novel Mo- $\mathrm{Si}_{3} \mathrm{~N}_{4}$ based selective coating for high temperature concentrating solar power applications. Sol. Energy Mater. Sol. Cells 122, 217225.

Cheng, J., Wang, C., Wang, W., Du, X., Liu, Y., Xue, Y., Wang, T., Chen, B., 2013. Improvement of thermal stability in the solar selective absorbing Mo-Al2O3 coating. Sol. Energy Mater. Sol. Cells 109, 204-208. 
Craighead, H.G., Buhrman, R.A., 1977. Optical-properties of selectively absorbing Ni$\mathrm{Al}_{2} \mathrm{O}_{3}$ composite films. Appl. Phys. Lett. 31, 423-425.

Craighead, H.G., Bartynski, R., Buhrman, R.A., Wojcik, L., Sievers, A.J., 1979. Metalinsulator composite selective absorbers. Sol. Energy Mater. 1, 105-124.

Du, M., Hao, L., Mi, J., Lv, F., Liu, X., Jiang, L., Wang, S., 2011. Optimization design of $\mathrm{Ti}_{0.5} \mathrm{Al}_{0.5} \mathrm{~N} / \mathrm{Ti}_{0.25} \mathrm{Al}_{0.75} \mathrm{~N} / \mathrm{AlN}$ coating used for solar Selective applications. Sol. Energy Mater. Sol. Cells 95, 1193.

Esposito, S., Antonaia, A., Addonizio, M.L., Aprea, S., 2009. Fabrication and optimisation of highly efficient cermet-based spectrally selective coatings for high operating temperature. Thin Solid Films 517, 6000-6006.

Farooq, M., Hutchins, M.G., 2002. Optical properties of higher and lower refractive index composites in solar selective coatings. Sol. Energy Mater. Sol. Cells 71, 7383.

Farooq, M., Green, A.A., Hutchins, M.G., 1998. High performance sputtered Ni:SiO2 composite solar absorber surfaces. Sol. Energy Mater. Sol. Cells 54, 67-73.

Feng, J., Zhang, S., Lu, Y., Yu, H., Kang, L., Wang, X., Liu, Z., Ding, H., Tian, Y., Ouyang, J., 2015. The spectral selective absorbing characteristics and thermal stability of SS/TiAIN/TiAlSiN/Si3N4 tandem absorber prepared by magnetron sputtering. Sol. Energy 111, 350-356.

Fernández-García, A., Zarza, E., Valenzuela, L., Pérez, M., 2010. Parabolic-trough solar collectors and their applications. Renew. Sustain. Energy Rev. 14, 16951721.

Granqvist, C.G., Hunderi, O., 1978. Optical properties of Ag-SiO2 cermet fils; a comparison of effective medium theories. Phys. Rev. B 18, 2897-2906.

International Energy Agency, 2014. Technology Roadmap, Solar Thermal Electricity.

Kennedy, C.E., 2002. Review of mid- to high-temperature solar selective absorber materials, NREL/TP-520-31267. National Renewable Energy Laboratory, Golden, $\mathrm{CO}$.

Kennedy, C.E., 2010. High Temperature Solar Selective Coatings, US patent 2010, 0313875 A1.

Kim, C.C., Garland, J.W., Abad, H., Raccah, P.M., 1992. Modeling the optical dielectric function of semiconductors: extension of the critical-point parabolic-band approximation. Phys. Rev. B 45, 11749-11767.

Lafait, J., Berthier, S., Sella, C., Vien, T.K., 1986. Pt-Al2O3 selective absorber coatings for photothermal conversion up to $600{ }^{\circ} \mathrm{C}$. Vacuum 36, 125-127.

Li, H., Belkind, A., Jansen, F., Orban, Z., 1997. An in situ XPS study of oxygen plasma cleaning of aluminum surfaces. Surf. Coat. Technol. 92, 171-177.

Maxwell Garnett, J.C., 1904. Colours in metal glasses and in metallic films. Philos. Trans. R. Soc. London 203, 385-420.

O Leary, S.K., Johnson, S.R., Lim, P.K., 1997. The relationship between the distribution of electronic states and the optical absorption spectrum of an amorphous semiconductor: an empirical analysis. J. Appl. Phys. 82, 3334-3340.

Pascual-Izarra, C., Reis, M.A., Barradas, N.P., 2006. Simultaneous PIXE and RBS data analysis using Bayesian Inference with the DataFurnace code. Nucl. Instrum. Methods Phys. Res. B 249, 780-783.

Peng, Y., Gong, J., Jiang, Y., Fu, M., Rong, D., 2016. The effect of plastic pre-strain on low-temperature surface carburization of AISI 304 austenitic stainless steel. Surf. Coat. Technol. 304, 16-22.

Rebouta, L., Pitães, A., Andritschky, M., Capela, P., Cerqueira, M.F., Matilainen, A., Pischow, K., 2012. Optical characterization of TiAlN/TiAlON $/ \mathrm{SiO}_{2}$ absorber for solar selective applications. Surf. Coat. Technol. 211, 41-44.

Rebouta, L., Sousa, A., Capela, P., Andritschky, M., Santilli, P., Matilainen, A., Pischow, K., Barradas, N.P., Alves, E., 2015. Solar selective absorbers based on Al2O3: W cermets and AlSiN/AlSiON layers. Sol. Energy Mater. Sol. Cells 137, 93-100.

Rebouta, L., Sousa, A., Andritschky, M., Cerqueira, F., Tavares, C.J., Santilli, P., Pischow, K., 2015. Solar selective absorbing coatings based on AlSiN/AlSiON/ AlSiO layers. Appl. Surf. Sci. 356, 203-212.

Selvakumar, N., Barshilia, H.C., 2012. Review of physical vapor deposited (PVD) spectrally selective coatings for mid- and high-temperature solar thermal applications. Sol. Energy Mater. Sol. Cells 98, 1-23.

Seraphin, B.O., 1976. Chemical vapor deposition of thin semiconductor films for solar energy conversion. Thin Solid Films 39, 87-94.

Shioji, M., Shiraishi, T., Takahashi, K., Nohira, H., Azuma, K., Nakata, Y., Takata, Y., Shin, S., Kobayashi, K., Hattori, T., 2004. X-ray photoelectron spectroscopy study on $\mathrm{SiO} 2 / \mathrm{Si}$ interface structures formed by three kinds of atomic oxygen at 300 ${ }^{\circ} \mathrm{C}$. Appl. Phys. Lett. 84, 3756-3758.

Sibin, K.P., John, Siju, Barshilia, H.C., 2015. Control of thermal emittance of stainless steel using sputtered tungsten thin films for solar thermal power applications. Sol. Energy Mater. Sol. Cells 133, 1-7.

Sunshot Vision Study, 2012. chap. 5: Concentrating Solar Power: Technologies, cost and performance, Feb 2012 (http://energy.gov/eere/sunshot/sunshot-visionstudy).

Teixeira, V., Sousa, E., Costa, M.F., Nunes, C., Rosa, L., Carvalho, M.J., Collares-Pereira, M., Roman, E., Gago, J., 2001. Spectrally selective composite coatings of $\mathrm{Cr}^{-} \mathrm{Cr}_{2} \mathrm{O}_{3}$ and $\mathrm{Mo}-\mathrm{Al}_{2} \mathrm{O}_{3}$ for solar energy applications. Thin Solid Films 392, 320.

Theiss, W., 2002. In: Theiss, M. (Ed.), SCOUT Thin Film Analysis Software Handbook. Hard-and Software, Aachen, Germany.

Trotter, D.M., Sievers, A.J., 1980. Spectral selectivity of high-temperature solar absorbers. Appl. Opt. 19, 711-728.

Uppachai, P., Harnchana, V., Pimanpang, S., Amornkitbamrung, V., Brown, A.P., Brydson, R.M.D., 2014. A substoichiometric tungsten oxide catalyst provides a sustainable and efficient counter electrode for dye-sensitized solar cells. Electrochim. Acta 145, 27-33.

Usmani, B., Dixit, A., 2016. Spectrally selective response of $\mathrm{ZrO}_{x} / \mathrm{ZrC}-\mathrm{ZrN} / \mathrm{Zr}$ absorber-reflector tandem structures on stainless steel and copper substrates for high temperature solar thermal applications. Sol. Energy 134, 353-365.

Viebahn, P., Lechon, Y., Trieb, F., 2011. The potential role of concentrated solar power (CSP) in Africa and Europe - a dynamic assessment of technology development, cost development and life cycle inventories until 2050. Energy Policy 39, 4420-4430.

Wäckelgård, E., Mattsson, A., Bartali, R., Gerosa, R., Gottardi, G., Gustavsson, F., Laidani, N., Micheli, V., Primetzhofer, D., Rivolta, B., 2015. Development of W$\mathrm{SiO}_{2}$ and $\mathrm{Nb}-\mathrm{TiO}_{2}$ solar absorber coatings for combined heat and power systems at intermediate operation temperatures. Sol. Energy Mater. Sol. Cells 133, 180193.

Wang, J., Wei, B., Wei, Q., Li, D., 2011. Optical property and thermal stability of Mo/ Mo- $\mathrm{SiO}_{2} / \mathrm{SiO}_{2}$ solar-selective coating prepared by magnetron sputtering. Physica Status Solidi (a) 208, 664-667.

Wong, H.Y., Ong, C.W., Kwok, R.W.M., Wong, K.W., Wong, S.P., Cheung, W.Y., 2000 Effects of ion beam bombardment on electrochromic tungsten oxide films studied by X-ray photoelectron spectroscopy and Rutherford back-scattering. Thin Solid Films 376, 131-139.

Xie, F.Y., Gong, L., Liu, X., Tao, Y.T., Zhang, W.H., Chen, S.H., Meng, H., Chen, J., 2012 XPS studies on surface reduction of tungsten oxide nanowire film by $\mathrm{Ar}^{+}$ bombardment. J. Electron Spectrosc.Related Phenom. 185, 112-118.

Yang, T., Zhang, Y., Li, C., 2014. Chemical and structural analysis of solvothermal synthesized tungsten oxide nanotube without template and its hydrogen sensitive property. J. Alloy. Compd. 584, 546-552.

Yin, Y., Collins, R.E., 1995. Optimization and analysis of solar selective surfaces with continuous and multilayer profiles. J. Appl. Phys. 77, 6485-6491.

Yue, Z.R., Jiang, W., Wang, L., Gardner, S.D., Pittman Jr., C.U., 1999. Surface characterization of electrochemically oxidized carbon Fibers. Carbon 37, 17851796.

Zhang, Q.C., Mills, D.R., 1992. Very low-emittance solar selective surfaces using new film structures. J. Appl. Phys. 72, 3013-3021.

Zhang, Qi-Chu, Shen, Y.G., 2004. High performance W-AlN cermet solar coatings designed by modelling calculations and deposited by DC magnetron sputtering Sol. Energy Mater. Sol. Cells 81, 25-37.

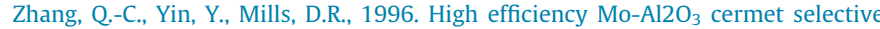
surfaces for high temperature application. Sol. Energy Mater. Sol. Cells 40, $43-$ 53.

Zhang, J., Tu, J.P., Xia, X.H., Qiao, Y., Lu, Y., 2009. An all-solid-state electrochromic device based on $\mathrm{NiO} / \mathrm{WO} 3$ complementary structure and solid hybrid polyelectrolyte. Sol. Energy Mater. Sol. Cells 93, 1840-1845.

Zheng, L., Gao, F., Zhao, S., Zhou, F., Nshimiyimana, J.P., Diao, X., 2013. Optical design and co-sputtering preparation of high performance Mo-SiO2 cermet solar selective absorbing coating. Appl. Surf. Sci. 280, 240-246. 